\title{
Evaluation of antianxiety effect of cinnamaldehyde in swiss albino mice
}

\author{
Ritesh Churihar ${ }^{1}$, Sapna A. More ${ }^{2 *}$, Pooja S. Mishra ${ }^{2}$, Savita Vyas², Hemant Tanwani ${ }^{2}$
}

\author{
${ }^{1}$ Department of Pharmacology, Government Autonomous Medical College, Ratlam, Madhya Pradesh, India \\ ${ }^{2}$ Department of Pharmacology, M.G.M. Medical College, Indore, Madhya Pradesh, India
}

Received: 27 August 2019

Revised: 07 October 2019

Accepted: 09 December 2019

\section{*Correspondence:}

Dr. Sapna A. More,

Email: drsapnaindore@yahoo.in

Copyright: (c) the author(s), publisher and licensee Medip Academy. This is an open-access article distributed under the terms of the Creative Commons Attribution Non-Commercial License, which permits unrestricted non-commercial use, distribution, and reproduction in any medium, provided the original work is properly cited.

\begin{abstract}
Background: Cinnamon is one of the best known spices used as an herbal medicine. Cinnamaldehyde (CNM) the volatile oil, which was present in the essential oil of the bark, is the important constituents of cinnamon. Cinnamon has been investigated for its various effects like peptic ulcer protection, antioxidant property, inhibition of tau aggregation, anti-inflammatory activity, effect on cardiovascular system, anti-nociceptive activity, hepato-protective effects, hypolipidemic and antidiabetic activites. The present study was aimed to evaluate the anxiolytic effect of CNM per se and its interaction with diazepam in swiss albino mice.

Methods: Anxiolytic activity was evaluated by elevated plus maze method. A group of 36 healthy mice of either sex weighing 20-30 grams were divided at random into six groups $(n=6)$. CNM and diazepam were dissolved in tween twenty $20 \%$ to maintain uniformity of the solvent and given orally. Group I was given twenty $20 \%$ (10 ml $/ \mathrm{kg}$, p.o.), group II diazepam (0.5 mg/kg, p.o.), group III diazepam (1 mg/kg, p.o.), group IV cinnamaldehyde (100 mg/kg, p.o.), group V cinnamaldehyde $(200 \mathrm{mg} / \mathrm{kg}$, p.o.), group VI cinnamaldehyde and diazepam (100 mg/kg and $0.5 \mathrm{mg} / \mathrm{kg}$, p.o.).

Results: Cinnamaldehyde per se showed no anxiolytic effect at any dose $(\mathrm{p}<0.05)$. The standard drug diazepam has shown significant anxiolytic activity on elevated plus maze. Whereas combination of diazepam $0.5 \mathrm{mg} / \mathrm{kg}$ and cinnamaldehyde $100 \mathrm{mg} / \mathrm{kg}$ showed significant increase in the time spent in open arms as compared to all groups $(\mathrm{p}<0.05)$.

Conclusions: CNM per se did not show any effect on anxiety but enhanced the action of diazepam when coadministered.
\end{abstract}

Keywords: Cinnamaldehyde, Diazepam, Elevated plus maze

\section{INTRODUCTION}

Anxiety is the most common type of central nervous system disorder and have affected the productivity of nations worldwide in terms of economic and manpower loss. Anxiety neurosis is accompanied by autonomic over activity leading to tachycardia, tremors, sweating and loss of confidence for work and in personal life. Neurotic disorders include anxiety neurosis, obsessive compulsive disorder, hysteria, social phobias, post-traumatic stress disorder and endogenous depression. Cinnamon is one of the oldest and best-known spices in the world and is used as a herbal medicine. ${ }^{1}$ It belongs to family Lauraece and is found in South India, Sri Lanka, Indonesia, Vietnam, Bangladesh and Nepal. Commonly known as Dal-chini, Darchini or Dhall cheene in Hindi. The active component of commercial cinnamon is the dried inner stem-bark of aromatic evergreen tree 10-15 meters tall. The most important constituents of cinnamon are cinnamaldehyde and eugenol, which are present in the essential oil of the bark thus contributing to the fragrance and to the various biological activities observed with cinnamon. ${ }^{2}$ Cinnamon 
has been investigated for peptic ulcer protection effects, antioxidant property, inhibition of tau aggregation, antiinflammatory activity, effect on cardiovascular system, anti-nociceptive activity, hepato-protective effects, antihyperlipidemic activity and as antidiabetic. ${ }^{3-12}$ The present study was planned to investigate whether cinnamaldehyde has anxiolytic activity per se and its interaction with diazepam.

\section{METHODS}

\section{Drugs and chemicals}

Cinnamaldehyde (CNM) with $98 \%$ purity was obtained from Science centre (Sunchem Pharma), Indore, Madhya Pradesh, India. Tween twenty was purchased from the same and was used as vehicle. Diazepam was procured from Maharaja Yashwantrao Holker hospital, Indore, M.P.

\section{Animals}

Swiss albino mice (20-30 gm) of either sex were used for the study. The animals were housed in polypropylene cages in central animal house. The rooms were maintained at the temperature of $25 \pm 5^{\circ} \mathrm{C}$ with 12 hour light/dark cycles. All the animal experiments were carried out according to the Committee for the Purpose of Control and Supervision of Experiments on Animals (CPCSEA), India guidelines. The animals were fasted overnight prior to the experiment and were given only water ad libitum The oral LD 50 of CNM in mice is 2.22 $\mathrm{g} / \mathrm{kg}$ body weight, as obtained from acute toxicity study. The study was approved by Institutional Animal Ethics Committee (IAEC), M.G.M. Medical College, Indore, India (IAEC-709/20/2010) and the work was conducted in the Department of Pharmacology, MGM Medical College, Indore, M.P.

\section{Preparation of drugs and grouping}

A group of 36 mice were divided at random into six groups ( $\mathrm{n}=6)$. CNM and diazepam (injectable, $10 \mathrm{mg} / 2$ $\mathrm{ml}$ from Ranbaxy limited) were dissolved in tween twenty $20 \%$ to maintain uniformity of the solvent and given orally. Group I was given Tween twenty 20\% (10 $\mathrm{ml} / \mathrm{kg}$, p.o.), Group II diazepam (0.5 mg/kg, p.o.), Group III diazepam (1 mg/kg, p.o.), Group IV CNM (100 mg/kg, p.o.), Group V CNM (200 mg/kg, p.o.), Group VI $\mathrm{CNM}$ and diazepam $(100 \mathrm{mg} / \mathrm{kg}$ and $0.5 \mathrm{mg} / \mathrm{kg}$, p.o. $){ }^{13}$

\section{Test model}

Elevated plus maze (EPM) is the simplest apparatus to study anxiolytic response of almost all type of antianxiety agents. Exposure of the animals to novel maze alley evokes an approach avoidance conflict which is stronger in open arm as compared to enclosed arm. Rodents have aversion for high and open space and prefer enclosed arm and therefore spend greater amount of time in enclosed arm. When the animals enter open arm, they freeze, become immobile, defecate and show fear like movements. The plasma cortisol level is also reported to be increased, as a true reflection of anxiety. ${ }^{14,15}$

\section{Equipment}

The elevated plus-maze was introduced by Listetil et al for mice. ${ }^{16}$ The elevated plus maze apparatus consisted of two open arms $(30 \times 5 \mathrm{~cm})$ and two closed arms $(30 \times 5 \times 20$ $\mathrm{cm})$ emanating from a common central platform $(5 \times 5$ $\mathrm{cm})$. The two pairs of identical arms were opposite to each other. The entire apparatus was elevated to a height of $50 \mathrm{~cm}$ above the floor level.

\section{Procedure}

The animals received the drugs as per the schedule an hour before the start of the session. At the beginning of the session, a mouse was placed at the centre of the maze, its head facing the closed arms and the total entries and total time spent in different arms were recorded. An entry was defined as the presence of all four paws in the arm. The elevated plus maze was carefully wiped, with $10 \%$ ethanol after each trial, to eliminate the possible bias due to the odour of the previous animal.

\section{RESULTS}

The number of entries in open arms, percentage preference towards the open arm and time spent in open arm were the criteria for the antianxiety effects.

Results were analyzed by one way ANOVA followed by Tukey's post hoc test for multiple comparisons amongst different groups. Results are expressed as mean \pm SEM. $\mathrm{P}<0.05$ was regarded as statistically significant.

Cinnamaldehyde per se showed no anxiolytic effect at any dose $(\mathrm{p}<0.05)$. The standard drug diazepam has shown significant anxiolytic activity on elevated plus maze $(p<0.05)$. Whereas combination of diazepam 0.5 $\mathrm{mg} / \mathrm{kg}$ and CNM $100 \mathrm{mg} / \mathrm{kg}$ showed significant increase in the time spent in open arms as compared to all groups $(p<0.05)$. Percentage preference for open arm entries was comparable between the combination group and the diazepam groups $(0.5 \mathrm{mg} / \mathrm{kg}$ and $1 \mathrm{mg} / \mathrm{kg})$.

No toxicity or mortality was observed during observation period of seven days after the completion of experiment.

\section{DISCUSSION}

In the present study, CNM was studied for its anxiolytic effect and its interaction with diazepam on elevated plus maze model.

Cinnamon has been documented to have numerous pharmacological activities. ${ }^{17,18}$ Either the different extracts or the active principle of cinnamon i.e. CNM have shown 
various activities. Till date its pharmacological activities like antimicrobial, anti-cancer activity have been proven but it has not been properly explored and results on various models of analgesia, antidepressant activity, extrapyramidal effects, anti-anxiety effects and sleeping time as well as its interaction with other drugs have been inconclusive.

Hence we evaluated cinnamon for anti-anxiety activity using animal model involving Swiss albino mice for the

Table 1: Effect of CNM per se and its interaction with diazepam (DZPM) on behaviour of albino mice in elevated plus maze model.

\begin{tabular}{|c|c|c|c|c|c|c|}
\hline \multirow{2}{*}{ Treatment } & \multirow{2}{*}{$\begin{array}{l}\text { Dose } \mathrm{mg} / \mathrm{kg} \\
\text { orally }\end{array}$} & \multicolumn{2}{|c|}{ Number of entries } & \multirow{2}{*}{$\begin{array}{l}\% \text { preference } \\
\text { to open arm }\end{array}$} & \multicolumn{2}{|c|}{ Time spent (sec) } \\
\hline & & Open & Total & & Open arm & Close arm \\
\hline Tween20 (20\%) & $10 \mathrm{ml} / \mathrm{kg}$ & $2.33 \pm 0.42$ & $5.33 \pm 0.61$ & 43.71 & $33.33 \pm 4.58$ & $325.00 \pm 5.79$ \\
\hline DZPM & 2.5 & $16.00 \pm 0.96^{* \#}$ & $25.00 \pm 1.18$ & 64.00 & $142.00 \pm 8.48^{* \#}$ & $218.00 \pm 8.48$ \\
\hline DZPM & 5 & $6.67 \pm 1.11^{* \#}$ & $9.67 \pm 1.38$ & 68.89 & $214.33 \pm 4.24^{* \#}$ & $144.00 \pm 4.17$ \\
\hline CNM & 100 & $1.83 \pm 0.30$ & $4.50 \pm 0.61$ & 40.66 & $36.67 \pm 8.46$ & $323.33 \pm 8.46$ \\
\hline CNM & 200 & $1.50 \pm 0.22$ & $4.00 \pm 0.44$ & 37.50 & $38.33 \pm 1.35$ & $321.67 \pm 4.31$ \\
\hline DZPM+CNM & $2.5 \pm 100$ & $5.50 \pm 0.67^{* \#}$ & $8.83 \pm 1.07$ & 62.28 & $322.50 \pm 8.09^{* \# \dagger}$ & $37.50 \pm 8.09$ \\
\hline \multirow{2}{*}{$\begin{array}{l}\text { One-way } \\
\text { ANOVA }\end{array}$} & $\mathrm{F}$ & 61.41 & 69.19 & & 339.53 & 322.99 \\
\hline & $\mathrm{P}$ & $<0.01$ & $<0.01$ & & $<0.01$ & $<0.01$ \\
\hline
\end{tabular}

One way ANOVA followed by multiple tukey's comparison test. Values are mean $\pm \mathrm{SEM}, \mathrm{n}=6, \mathrm{df}=5,30 ;{ }^{*} \mathrm{p}<0.05$, compared to control; $\# \mathrm{p}<0.05$, compared to CNM 100 and $200 \mathrm{mg} / \mathrm{kg}$ groups; $\dagger \mathrm{p}<0.05$, compared to diazepam 2.5 and $5 \mathrm{mg} / \mathrm{kg}$. DZPM: diazepam.
Diazepam has shown antianxiety effects at both therapeutic $1 \mathrm{mg} / \mathrm{kg}$ and sub therapeutic dose of 0.5 $\mathrm{mg} / \mathrm{kg}$ with significant difference as compared to control. CNM at doses of $100 \mathrm{mg} / \mathrm{kg}$ and $200 \mathrm{mg} / \mathrm{kg}$ did not produce any significant change in above parameters. However CNM at $100 \mathrm{mg} / \mathrm{kg}$ when combined with subtherepeautic dose of diazepam $(0.5 \mathrm{mg} / \mathrm{kg})$ showed significant enhanced antianxiety effects (time spent in open arm) as compared to diazepam $1 \mathrm{mg} / \mathrm{kg}$ alone $(p<0.05)$. However, the percentage preference for open arms was comparable among the combination and standard groups, with no statistically significant difference (Table 1).

The likely mechanism behind the enhancement of the antianxiety effects of diazepam could be either due to altered pharmacokinetics of diazepam by CNM, favouring its absorption or reducing its metabolism or excretion. There could also be complex formation which has better CNS entry. There could be an effect on the plasma protein binding, increasing availability of free diazepam in the blood. A study done by de Moura et al on CNM at 30 and $50 \mathrm{mg} / \mathrm{kg}$ also concluded that CNM does not possess any anxiolytic activity and in our study even the higher doses of CNM lack the anxiolytic activity. ${ }^{13}$

The pharmacokinetic reasons may be responsible for the enhancement of action of diazepam. This could be due to increased blood flow due to gastrontestnal irritation with consequent enhanced absorption. CNM may be improving the absorption of drugs, perhaps by increasing gastrointestinal blood flow by vasodialatation. $3,7,11,13$ experiment. We conducted our experiment using the active principle CNM, which was obtained from Science se as well as its interaction with the established standard anxiolytic drug diazepam using elevated plus maze was observed. The number of entries in open arms, percentage preference towards the open arm and time spent in open arm were the criteria for the antianxiety effects. Centre, Indore having $98 \%$ purity. The effect of CNM per

Further studies are needed to reveal the exact mechanism of action responsible for the enhanced activity of diazepam and thiopental sodium. So the addition of CNM may reduce the required dose of diazepam that may help in reduction of toxicity. Hence further studies are required to acknowledge these facts.

\section{ACKNOWLEDGEMENTS}

The authors are grateful to acknowledge Dr. Pooja Solanki, Professor and Head, Department of Pharmacology, M.G.M. Medical College, Indore, (M.P.) for his guidance and support in carrying out the work.

Funding: No funding sources

Conflict of interest: None declared

Ethical approval: The study was approved by the Institutional Ethics Committee

\section{REFERENCES}

1. Sharma HL, Sharma KK. Principles of Pharmacology, 1st edition: Nature and sources of drugs, New Delhi, Paras publishing; 2007: 977.

2. Sharma HL, Sharma KK. Principles of Pharmacology, 1st edition: Nature and sources of drugs, Paras publishing; 2007: 176-179.

3. Tapsell LC, Hemphill I, Cobiac L et al. Health benefits of herbs and spices: the past, the present, the future. Med J Aust. 2006;185(4):4-24.

4. Ram A, Lauria P, Gupta R, Kumar P, Sharma VN. Hypocholesterolaemic effects of Terminalia arjuna tree bark. J Ethnopharmacol. 1997;55:165-9. 
5. Jarvill-Taylor KJ, Anderson RA, Graves DJ. A hydroxychalcone derived from cinnamon functions as a mimetic for insulin in 3T3-L1 adipocytes. J Am Coll Nutr. 2001;20:327-36.

6. Newman DJ, Cragg GM, Snader KM. Natural products as sources of new drugs over the period 1981-2002. J Nat Prod. 2003;66:1022-37.

7. Guidelines for the regulation of herbal medicines in the South-East Asia Region World Health Organization Regional Office for South-East Asia. Available at: http://www.searo.who.int/LinkFiles/ Reports_TradMed82.pdf. Accessed on 2 August 2019.

8. Available at: http://crdd.osdd.net/indipedia/index. php/Medicinal_plants_of_India. Accessed on 2 August 2019.

9. Lai PK, Roy J. Antimicrobial and chemopreventive properties of herbs and spices. Curr Med Chem. 2004;(11):1451-60.

10. Fabricant DS, Farnsworth NR. The value of plants used in traditional medicine for drug discovery. Environ. Health Perspect. 2001;109(1):69-75.

11. Cox PA. Ciba Foundation Symposium 154, Chichester: John Wiley Sons; 1990: 40.

12. Cox P, Balick M. The ethnobotanical approach to drug discovery. J Sci Am. 1994:270(6):82-87.

13. Moura JC de, Noroes MM, Rachetti Vde P, Soares BL, Preti D, Nassini R, et al. The blockade of transient receptor potential ankirin 1 (TRPA1) signalling mediates antidepressant- and anxiolyticlike actions in mice. $\mathrm{Br} \mathrm{J}$ Pharmacol. 2014;171:4289-99.

14. Pellow S, Johnstan AL, File SE. Selective agonists and antagonists for 5-hydroxytryptamine receptor subtypes, and interaction with yohimbine and FG 7142 using the elevated plus-maze test in the rat. $\mathbf{J}$ Pharm Pharmacol. 1987;39:917-28.

15. Sharma AC, Kulkarni SK. Evaluation of learning and memory mechanisms employing elevated plus-maze in rats and mice. Pro Neuro-Psychopharmacol BiolPsychiat. 1992;16:117-25.

16. Lister RG. The use of a plus-maze to measure anxiety in the mouse. Psychopharmacol. 1987;92:180-5

17. Rao PV, Gan SH. Cinnamon: A Multifaceted Medicinal Plant. Hindawi Publishing Corporation Evidence-Based Complementary Alternative Medicine. 2014;642942:12.

18. Sangal A. Role of cinnamon as beneficial antidiabetic food adjunct: a review. Adv Appl Sci Res. 2011;2(4):440-50.

Cite this article as: Churihar R, More SA, Mishra PS, Vyas S, Tanwani H. Evaluation of antianxiety effect of cinnamaldehyde in swiss albino mice. Int $\mathbf{J}$ Basic Clin Pharmacol 2020;9:85-8. 